Edukacja i satyra. Przyczynek do analizy koncepcji wychowawczych i dzialalności oświatowej Franciszka Salezego Jezierskiego

Bronisław Treger 


\section{Bronisław Treger}

\section{Edukacja i satyra. \\ Przyczynek do analizy \\ koncepcji wychowawczych i działalności oświatowej \\ Franciszka Salezego Jezierskiego}

乙ariera pedagogiczna księdza Jezierskiego ${ }^{1}$ była — na dobre i na złe — powiązana z jego Kuzdolnieniami i temperamentem krasomówczym. Kanonik Jezierski 20 września 1781 zostaje przyjęty do stanu nauczycielskiego, zobowiązuje się do przestrzegania projektu Ustaw Komisji Edukacji Narodowej dla stanu akademickiego i na szkoty w krajach Rzeczypospolitej przepisanych i niezadługo obejmuje obowiązki rektora szkół lubelskich stanu akademickiego ${ }^{2}$. Ponieważ wydział lubelski składal się w przeważającej mierze ze szkół pijarskich, to po utworzeniu samodzielnego wydziału szkół owego zakonu pod zwierzchnością Jezierskiego utrzymała się tylko szkoła w Lublinie. Po kolejnym przetasowaniu organizacyjnym w połowie 1783 roku kanonikowi powierzono rządy nowo powołanego wydziału małopolskiego, obejmującego szkoły akademickie w Krakowie, Pińczowie, Sandomierzu, Lublinie i komunistów w Kielcach.

Hugo Kołłątaj w liście do Szczepana Holowczyca, pisanym w obronie Jezierskiego przed zarzutami szlachty łęczyckiej, przypomina, iż

\footnotetext{
' Kwestie dotyczące biografii kanonika niżej podpisany rozpatrywał - odwolując się do odpowiedniej literatury przedmiotu - w artykule Kaznodzieja i prześmiewca. Uwagi o niektónych zagadnieniach twórczości i życia Franciszka Salezego Jezierskiego, „Napis”, seria V, 1999, s. 95-119.

2 Zob. W. Smoleński, Kuźnica Kotlątajouska, w: idem, WÝór pism, Warszawa 1954, s. 277-278; Z. Kukulski, Pierwsi nauczyciele śtvieccy' $w$ Szkole Wydziatowej Lubelskiej w dobie Komisji Edukacji Narodowej, Lublin 1939, s. 62.
} 
J. ks. Jezierski, nim został przyjęty do stanu akademickiego, będąc kanonikiem kolegiaty kaliskiej, służył tamtemu kościołowi pracą kaznodziejską przez lat kilka, był cenzorem książek w archidiecezyi gnieźnieńskiej, zjednał sobie szacunek i przychylność obywatelów wielkopolskich, którzy się za nim interesowali, aby mógł być użyty do posług edukacyjnych. Z woli P[rześwietnej] Komisyi, a za szczególną laską J. O. kscia Jmci został rektorem wydziału małopolskiego. Nalazł się naówczas w gnieździe swoim, to jest w województwie lubelskim, gdzie zjednywał sobie przychylność od obywatelów i zwierzchności duchowej ${ }^{3}$.

Nie będzie chyba przesadą stwierdzenie na podstawie przytoczonego wyimka z korespondencji reformatora wszechnicy krakowskiej, że Jezierski przychylność i szacunek obywatelów wielkopolskich zyskał sobie raczej jako kaznodzieja niz jako cenzor. Do sprawy zatargu z Łęczycaninami powrócę w nieco dalszej części szkicu. Najpierw poświęcę chwilę uwagi działalności oratorskiej kanonika z czasów lubelskiego rektorowania.

\section{Edukacja ojców, edukacja dzieci}

Zgodnie z dzisiejszym stanem badań wiadomo o trzech zachowanych wystapieniach rektora szkół wydziałowych lubelskich ${ }^{4}$. Ze względu na tematykę niniejszego przyczynku najbardziej interesująca spośród nich jest Do Najjaśniejszego Trybunatu Koronnego przez ks. Franciszka Salezego z Gotąbków Jezierskiego, kanonika kolegiaty kaliskiej, rektora wydziatowego lubelskiego imieniem szkót na miejscu nauk o naukach, przy powitaniu powiedziana mowa ${ }^{5}$. W oracji tej - po stosownych powitaniach — Jezierski pochwala reformy oświatowe KEN,

...dzieło pierwszem przytrafieniem zdarzone między wiekami i pierwiastkowem wykonaniem ozdabiające naród nasz pamiątką chwały mimo jego nieszczęścia ${ }^{6}$.

Zanim jednak przejdzie do właściwego toku swych wywodów, wtrąca paradoksalnie zabarwione zdanie:

Rzecz zdaje się być zadziwiająca rozum, co powiem, ale przeto nie przestająca być prawdą, że przez wszystkie wieki we wszystkich narodach każdy kraj usiłował być ojczyzną ojców, nie starając się być ojczyzną ich dzieci ${ }^{7}$.

\footnotetext{
${ }^{3}$ H. Kołłątaj, list do S. Hołowczyca z 17 IX 1785, w: K. Mrozowska, Walka o nauczycieli świeckich w dobie Komisji Edukacji Narodowej na terenie Korony, Wrocław 1956, s. 335-336.

4 Wszystkie związane z sesjami Trybunalu Koronnego dla prowincji małopolskiej, zob. idem, Dwva wystapienia trybunalskie, opr. B. Treger, „Napis”, seria V, 1999, s. 87-94; Mowa przy obchodzeniu pamiątki stu lat zuycięstwa pod Wiedniem Jana III miana w Lublinie, opr. B. Treger, „Napis”, seria VII, s. 359-369.

${ }_{5}^{5}$ Tenże, Dwa wystapienia..., s. 87-89.

${ }^{6}$ Ibidem, s. 87.

${ }^{7}$ Loc. cit.
} 
Na pierwszy rzut oka konstatacja powyższa może być traktowana jako jeden z typowych zabiegów retorycznych okraszających wystąpienie i przyciągających swą niezwyczajnością uwagę słuchaczy. Czyż retorzy od najdawniejszych czasów nie lubowali się w żonglowaniu zaskakującymi konceptami i paradoksami? Na zasadzie paradoksu konstruowano nieraz całe wystąpienia. Arystoteles w Retoryce zwraca uwagę na następującą praktykę krasomówczą:

...zdarza się często, że wygłaszamy poważnie lub żartobliwie pochwały, nie tylko czlowieka lub boga, lecz również przedmiotów nieożywionych i jakichś najmarniejszch nawet zwierząt ${ }^{8}$.

Nie trzeba jednakowoż zbytnio natężać uwagi, by zauważyć zasadniczą różnicę między treścią przytoczonej tu wypowiedzi Jezierskiego a na przykład tezą Polikratesa o wspaniałych pożytkach, jakie przynoszą ludziom myszy ${ }^{9}$. Pogląd starożytnego sofisty i logografa rozpatrywany serio jest bezdyskusyjnie nonsensowny, zaś aforyzm rektora szkół lubelskich tylko pozornie opiera się na grze słów. Ważniejsza niż forma jest zgoła nieblaha problematyka owej sentencji. Na pewno nie jest przypadkiem, że do mniej lub bardziej podobnej gry słów sięga pisarz i myśliciel żyjący sto kilkadziesiąt lat później. Czytamy u Gombrowicza:

Do diabla z Ojcem i Ojczyzną! Syn, syn, to mi dopiero, to rozumiem! A po co tobie Ojczyzna? Nie lepsza Synczyzna? Synczyzną ty Ojczyznę zastąp, a zobaczysz! ${ }^{10}$

Mówiąc o nieprzypadkowości, nie sugeruję tu oczywista, iżby Gombrowicz zapożyczal się u kanonika. Rzecz ma o wiele prostsze wyjaśnienie. Obydwaj mistrzowie pióra za pomocą częściowo przynajmniej podobnych zwrotów wyrażają swój krytyczny stosunek do pewnych uporczywie trwających, rozlegle zakorzenionych $\mathrm{w}$ dziedzictwie przeszłości poglądów i wyobrażeń społecznych, które ich zdaniem stają się dokuczliwą zawadą na drodze niezbędnych przemian socjalnych, oświatowych, obyczajowych... - najogólniej ujmując: cywilizacyjnych $^{11}$.

${ }^{8}$ Arist. Rhet., 1336 a, th. H. Podbielski.

'Zob. ibidem, $1401 \mathrm{~b}$.

${ }^{10}$ W. Gombrowicz, Trans-Atlantyk, Kraków 1986, s. 61.

"Bieg czasu, z należącymi doń nieuchronnie burzami dziejowymi, nierzadko rujnuje nawet posadowione na najbardziej - wydawołoby się — masywnych fundamentach instytucje spoleczne. „Po 1945 roku ewolucja systemów wyobrażeń ojcostwa nie jest ani linearna, ani ciagla. Aż do lat 1968-70 dokonuje się ona powoli. Zaznacza się stopniowa utrata władzy i autorytetu i pojawia się pojęcie ojca uchybiającego swym obowiązkom w specyficzny dla okresu powojennego sposób. Jest to czas zmierzchu modelu ojca, według Lacana, który od 1938 roku poszukiwał spolecznych i rodzinnych przyczyn tego zjawiska i wskazywał na jego skutki psychologiczne. Proces ten zacząl się jeszcze przed 1945 rokiem, lecz uwidocznił się w całej swej rozciagglości po zakończeniu II wojny światowej, gdy wrócili do domów jeńcy wojenni, czujący się obco wobec wlasnych dzieci, które wyrosły bez ich wplywu. (...) Aż do 1960 roku burżuazyjny model pater familias był stopniowo podważany, a po tej dacie już otwarcie kwestionowany, zaś w maju 1968 gwaltownie atakowany. Ostatni pater familias zostal uśmiercony w 1970 roku, gdy reforma władzy rodzicielskiej obaliła władzę ojcowską. (...) Zastępuje ona mianowicie termin władza ojcowska sformulowaniem władza rodzicielska, to znaczy władza, 
Dalszy ciąg wystąpienia rektora wydziałowego przygłusza krytyczny wydźwięk początkowego aforyzmu o ojczyznach ojców, a nie dzieci, jako o zjawisku powszechnym w dziejach Jezierski dokonuje bardzo pobieżnego, ale calkiem interesującego przeglądu historii edukacj w krajach europejskich. Przypomina, że miejscem narodzin europejskiej nauki i oświaty była Grecja, jest zdania, że nad duchowością Hellenów zaciążyła spekulacja filozoficzna, skłonność do mnożenia szkół gloszących radykalnie nieraz odmienne poglądy:

Grecyja kolebka nauk w Europie, atoli szła zawsze za zdaniem fantazyi filozofów, a każde mniemanie ich osobnych składało naśladowców ${ }^{12}$.

Rzymianie - kontynuuje kanonik - byli w dziedzinie kultury uczniami Greków, w zdobytym mieczem imperium wprowadzili sprawne rządy, ich państwo nie rozpadłoby się pod ciosami barbarzyńskich najazdów, gdyby potrafili zbudować odpowiedni system edukacyjny:

Trwali długo dobrym rządem pokoju i wojny, trwaliby może dłużej, żeby wychowanie młodzieży ich było powszechne i powaga kraju stwierdzone ${ }^{13}$.

W tym miejscu rektor lubelski wypowiada myśl przewodnią swej mowy - myśl, do której będzie powracał także w późniejszych publikacjach - że kwestia wychowania i nauczania mlodych pokoleń winna być jednym z najgłówniejszych przedmiotów troski naczelnych władz dobrze urządzonego społeczeństwa.

W wiekach średnich — nadmienia w kolejnej części swej przemowy Jezierski — pojawiają się zalążki odrodzenia oświaty i nauki. Szczególnie doniosłą rolę w tych przeobrażeniach umysłowych odegrały uniwersytety i inne uczone instytucje. Wladze zwierzchnie poszczególnych państw czy innych samodzielnych bytów politycznych nie przejawiały jednakże należytej pieczy nad sprawami kształcenia młodych pokoleń.

W bliższych nam wiekach gdy religija prawdziwa świat ujęła swojemi prawdami, kilka osad literatury pod imieniem akademij wydźwignąwszy się spośrzód dzikości i grubości barbarzyńców światłem swojem zaczęli oświecać przesądy. Jednak te hierarchije nauk bez dokładania się najwyższej zwierzchności przystawiali zdania dla mlodzieży mającej być obywatelami kraju ${ }^{14}$.

która przysługuje ojcom i matkom celem zapewnienia dziecku bezpieczeństwa, zdrowia i moralności. Nie ma już więc jednej głowy rodziny, to jest ojca, lecz dwie władze: ojciec i matka, które zresztą mają wobec dzieci więcej obowiązków niż praw. Pater fanilias, którego początki wywodzą się jeszcze z prawa rzymskiego, zniknął z prawodawstwa, tak jak zniknąl z obyczajów" (Historia ojców i ojcostıva, red. J. Delumeau, D. Roche, Warszawa 1995, s. 373, 374). Choć przytoczony wywód odwoluje się głównie do realiów francuskich, to wnioski zeń wypływające mogą być stosowane - mutatis mutandis — do całego zachodniego świata.

12 F. S. Jezierski, Dwa uystqpienia..., s. 88.

${ }^{13}$ Loc. cit.

${ }^{1+}$ Loc. cit. 
Kanonik podkreśla doniosłe znaczenie działalności wladców mecenasów wiedzy; ale i tu niczym refren powraca napomnienie, iż nikt $z$ owych panujących nie pokusił się o zinstytucjonalizowanie edukacji narodowej.

I lubo nasza część świata miała wielkich mężów w osobach monarchów odnawiających gust nauk, jako to Franciszek I w Francyi, Leo X w Rzymie, Mediceusz w Florencyi, Kazimierz W[ielki] i Władysław Jagiełlo w Polszcze, monarchowie ci jednak byli dobrodziejami umiejętności, to jest prawda, ale nie byli nigdy jej rządzicielami ${ }^{15}$.

Przyszedł czas na kulminację panegiryczną mowy. Rektor wydziałowy lubelski nie może wprost nachwalić przed Najwyższym w Królestwie Sądem zasług aktualnie panującego króla na polu organizacji instytucjonalnej wychowania młodzieży i upowszechniania rozbudowanych i roztropnych programów edukacyjnych. W oracji kanonika Stanisław August wyrasta na postać o znaczeniu przełomowym w skali niemalże powszechnodziejowej ${ }^{16}$.

A królestwa najlepiej oświecone myśląc o rządzie, obronie, sprawiedliwości i bogactwach kraju nie zatrudniły się nigdy ustawami około ćwiczenia młodzieży. Gdy przypadkowa pobożność budowała cały sposób myślenia, który miał składać na dalsze życie ducha obywatelskiego, Najjaśniejszy Stanisław August król narodu naszego wielkością duszy swojej uprzedza przyszłość wieków swoją troskliwą przezornością o dobro powszechne a tak wyraźnie potrzebne,

15 Loc. cit.

${ }^{16}$ Mimo to, w kilka lat później, gdy zaszła taka - wynikająca z aktualnej linii politycznej Kuźnicy — potrzeba, pisze Jezierski tekst zawierający bezpardonowe ataki na Stanisława Augusta. Na przykład tak oto przedstawia jego postępowanie w czasie konfederacji barskiej: „Król wolnego narodu siedząc spokojnie w stolicy kraju nadsłuchiwał powodzeń wojsk narodu nazwanego od stolicy, a każde rozlanie krwi jego poddanych było czczone powinszowaniem ministrowi od monarchini przebywającemu przy jego dworze. Wojska narodu nazwanego od stolicy, podług swego okrutnego przyrodzenia, zabranych sprzymierzeńców na wojnie częścią przedawali do postronnych państw, częścią ucinali ręce wiecznym kalectwem oznaczając dzikość swojego okrucieństwa. (...) Smutny widok: przyjaciel króla nieprzyjacielem narodu jego" (F. S. Jezierski, Tron dla próżnej pouagi, szlachta do poddaństwa ..., opr. B. Treger, „Napis”, seria IV, 1998, s. 119). Tekst nie zostal wówczas opublikowany, bowiem zmieniły się układy polityczne i Kołłątaj (ówczesny protektor polityczny kanonika) porozumiał się z królem.

Jezierski aż do śmierci pobierał pensję od Stanisława Augusta. Pierwsza wzmianka o pensji znajduje się w liście kanonika do króla z 3 lipca bez daty rocznej (1788 albo 1789) w którym skarży się na kłopoty z jej otrzymywaniem (zob. W. Smoleński, Kuźnica Kollątajowska, s. 291); ostatnia z podziękowaniem dla króla za pensję z loża śmierci znajduje się w liście Naruszewicza z 15 lutego 1791 roku do monarchy, informującym o zgonie ks. Franciszka Salezego (Korespondencja Adama Naruszewicza 1762-1796, wyd. J. Platt, Wrocław 1959, s. 391; datację listu, a co za tym idzie i śmierci kanonika podaję za: M. Pasztor, Hugo Kottątaj na Sejmie Wielkim w latach 1791-1792, Warszawa 1991, s. 18). Nie można więc wykluczyć z całą pewnością sytuacji, że kanonik gotów byl napastować króla, jednocześnie inkasując odeń pensję - Tron... znajdowal się na warsztacie Jezierskiego w pierwszym kwartale 1789 roku; ostatnie wydarzenie polityczne, o którym napomyka się w manuskrypcie, to uchwalenie ofiary dziesiątego grosza (26 III 1789) po obaleniu Rady Nieustającej (zob. B. Treger, Kottątaj czy Jezierski? Zagadnienie autorstwa „Tronu dla próżnej powagi...”, „Napis”, seria IV, 1998, s. 77). 
i stanowi w powadze najwyższej władzy i przełożeństwo nauk, i sposób podawania ich $(\ldots)^{17}$.

Króciutki ów pean na cześć monarchy kończy się tekstem będącym najzwięźlejszym a jednocześnie niebanalnym i trafnym ukazaniem nobilitowanych „troskliwą przezornością" Stanisława Augusta celów programowych szkolnictwa Komisji Edukacji Narodowej:

...uczymy poznawać naturę w historyi naturalnej; w nauce obyczajów - cnoty i prawdy; w fizyce - doświadczenia; w loice - myślenia sposobu; w wymowie - składnego tłómaczenia myśli; piękności stworzonego świata chcemy widzieć przez miarę i liczbę; historyja dziejów ozdabia wiadomością pamięć; a nie chcąc wody po powietrzu prowadzić, uczymy lacińskiego języka po polsku.

Przedstawienie idei przewodniej reformy programu edukacji ${ }^{18} \mathrm{w}$ postaci dobitnej, lapidarnej, przyciągającej uwagę i zapadającej w umysł formuły słownej było możliwe nie tylko dzięki zręczności retorycznej kanonika. O wiele ważniejsze znaczenie niż talent krasomówczy miały lektury i rozmyślania Jezierskiego nad dziejami kultury polskiej i europejskiej ${ }^{19}$, w szczególności nad przeobrażeniami nauki i edukacji. Ów wysiłek intelektualny zaowocowal znajomością problematyki pedagogicznej. Swiadectwem jest nie tylko analizowana i cytowana powyżej oracja lubelska, lecz również inne - późniejsze — publikacje.

\section{Edukacja a badania naukowe}

W Niektórych wyrazach napotkamy między innymi dwa bardzo interesujące z punktu widzenia tematyki niniejszego przyczynku hasła-minieseje: Edukacyja i Nauki. W drugim $z$ tych szkiców autor rozważa kwestię początków i ewolucji wiedzy naukowej. Sięga głębiej

\footnotetext{
${ }^{17}$ F. S. Jezierski, op. cit.

${ }^{18}$ Ustanowienie Komisji Edukacyjnej niepomiernie pobudzilo dyskusje nad teoretycznymi i praktycznymi zagadnieniami pedagogiki. Sposobność obeznania się z poziomem i zakresem tychże dyskusji daje antologia tekstów pt. Pisma i projekty pedagogiczne doby Komisji Edulaacji Narodowej, wyb. i opr. K. Mrozowska, Wroclaw 1973.

${ }^{19}$ Wiedzę historyczną Jezierskiego doceniali, znający go osobiście, tak wybitni przedstawiciele elity intelektualnej polskiego oświecenia jak Kołłątaj i Jan Śniadecki. Autor Listów Anonima informuje o wykształceniu swego wspólpracownika: ,(..) nauki duchowne składając szkolę misjonarzów, stały się mocnym fundamentem i prawidlem wszystkich wiadomości, których w ciągu życia swego nabyl; w teologiji i historyi kościelnej biegły, uformował się na bardzo dobrego kaznodzieję. (...) Ksiądz Jezierski okazawszy swą zdatność w pracach apostolskich pod okiem Kierskiego [Józefa Tadeusza, biskupa przemyskiego w latach 1768-1783 - B. T.] udał się potym do Włoch, gdzie wiadomości swoje bardziej jeszcze rozszerzyl, a do nauk duchownych dodał gruntowną umiejętność historyi krajowej i powszechnej” (H. Kołłątaj, Przedmowa, w: F. S. Jezierski, Niektóre wyrazy porządkiem abecadla zebrane i stosownymi do rzeczy uwagami objaśnione, Warszawa 1791, s. X, XI). Sniadecki powiada, że kanonik „Pełen był ducha starożytnych naszych polskich pisarzy, których dobrze mógł naśladować, gdy mu tego było do ukrycia się potrzeba. Wielką miał wiadomość historyi krajowej" (J. Śniadecki, Uwagi nad „Historyja literatury polskiej”, przez Feliksa Bentkowskiego w tomie I, $w$ Warszauvie 1814, w: M. Baliński, Pamiętniki o Janie Sniadeckim, jego życiu prnvatnym i publicznym i dzielach jego, Wilno 1865, s. 393).
} 
w przeszłość niż czynił to w mowie do Trybunału Koronnego i - zgodnie z osiemnastowiecznym stanem znajomości historii - konstatuje, że kolebka nauk znajdowala się na Bliskim Wschodzie, oraz że niezbyt wiele o owych wczesnodziecięcych latach można powiedzieć.

Trzeba posunąć uwagę przezierając pamięcią w najodleglejszą starożytność, aby dojźrzeć w społeczeństwach ludzkich jakiegokolwiek wyobrażenia nauk, to co nam wystawia historyja $z$ narodami, to samo można z naukami uważać. Chaldejczykowie, Asyryjczykowie mieli okazale panowanie na ziemi i u nich były nauki, jak zaś nie można wiedzieć dokładnie ich rządu, handlu, religiji, tak też stanu ich nauk domyślić się jest niepodobieństwo ${ }^{20}$.

Dalszy tok rozmyślań kanonika poświęcony jest kolejom oraz osobliwościom wędrówki i rozwoju idei naukowych. Jedną z ważnych prawidłowości określających proces rozprzestrzeniania się wiedzy Jezierski przedstawia w postaci efektownego i trafiającego w sedno aforyzmu:

Jednakże, gdzie pierwej nauki były wszczęte, los tego kraju przeciwny nie zawsze potrafił ich wygasić, nauki są w udzielaniu się swoim na kształt ognia, którego nie zawsze ubywa, choć od niego zapalają rzeczy insze ${ }^{21}$.

Materią historyczną obrazującą rzeczoną zasadę są przeobrażenia nauki starożytnej. Kanonik odnotowuje, iż Grecy byli uczniami Egipcjan - mistrzowie zostali prześcignięci przez terminatorów, jednakże kultura egipska nie utraciła przez to swych sił żywotnych. Dalej: Grecy - choć podbici siłą oręża przez Rzymian - mocą swych umiejętności duchowych zapanowali nad umysłami agresorów. Ateny aż do zmierzchu antyku pozostały jednym z głównych centrów cywilizacyjnych śródziemnomorskiego świata.

Egipt podał nauki Grekom, trwały atoli dlugo nauki w Egipcie mimo rozmaite uciemiężenia złej doli tego narodu. Grecyja, obrócona w prowincyją rzymską, straciła panowanie, ale Ateny długo bardzo zostawały w powadze umiejętności swojej $^{22}$.

Można się zastanawiać, czy w rozpatrywanym fragmencie rozumowania Jezierskiego nie pobrzmiewają echa słów Horacego Graecia capta ferum victorem cepit (Epist. II 1, 156).

Naszkicowane przez Jezierskiego z bardzo ogólnej - chciałoby się powiedzieć historiozoficznej - perspektywy rozważania nad dziejami i treścią badań naukowych są powiązane $z$ jego zapatrywaniem na generalną klasyfikację nauk.

\footnotetext{
${ }^{20}$ F. S. Jezierski, Niektóre wyrazy porządkiem abecadla zebrane i stosownymi do rzeczy unvagami objaśnione, Warszawa 1791, s. $139-140$.

${ }^{21}$ Ibidem, s. 140.

22 Loc. cit..
} 
Należy przyznać, że własny ${ }^{23}$ podział nauk (idąc za podziałem natury człowieka) dzielić się powinien na naukę fizyki i na naukę obyczajów; pierwsza ma w zamiarze uważanie rzeczy, które otaczają zmysły, druga ma cel potykające rzeczy i wewnętrzne czucie; i pierwsze zaś, i drugie nauki wspierać się powinny koniecznie na powadze prawdy ${ }^{24}$.

W koncepcji tej widać zdystansowanie się wobec tradycyjnych podziałów umiejętności a zwłaszcza rozczłonkowania tożsamego $z$ uświęconym układem fakultetów uniwersyteckich.

Stan nauk w Europie pod powaga gotyckiego wieku — powiada kanonik zaczął dzielić rozum na to czworakie zażycie w akademijach, na filozofiją, na lekarską naukę (która jest sercem fizyki) na prawo i na naukę wiary ${ }^{25}$.

Jezierskiego „własny podział nauk” nie powinien być rozpatrywany w oderwaniu od tła intelektualnego, jakim była wielowątkowa - niejednokrotnie wkraczająca w sferę polityki — i bez wątpienia inspirująca debata o przebudowie systemu oświaty narodowej ${ }^{26}$. Bez trudu da się zauważyć ramową zgodność przedstawionego w Niektórych wyrazach podziału z wprowadzonym przez KEN za czasów rektorstwa Kołlątaja głównym schematem organizacyjnym Akademii Krakowskiej. Kołłątaj raportuje:

W roku [17]83 wyszły powtórnie Ustawy P[rześwietnej] Komisji, dzielące wszystkie nauki w Szkole Głównej na dwa tylko Kolegia, to jest na Fizyczne i na Moralne, gdzie dopiero naznaczyć można prawdziwą epochę widocznego urządzenia Szkoły Głównej co do nauk w niej rozpoczętych ${ }^{27}$.

${ }^{23}$ Rzecz jasna słowo „własny” należy w tym kontekście rozumieć jako „prawdziwy, (...) istny, doskonały, (...) zupełny, (...) wahrhaftig, vollkommen" (S. B. Linde, Stownik jezzka polskiego, t. 6, cz. 1, Lwów 1860, s. 351): „wlaściwy, prawdziwy, rzetelny, trafny, istotny, rzeczywisty, należyty” (J. Karłowicz, A. Kryński, W. Niedźwiecki, Slownik języka polskiego, t. 7, Warszawa 1919, s. 651).

${ }^{2+}$ F. S. Jezierski, op. cit., s. 143.

${ }_{25}$ Ibidem, s. 145-146.

${ }^{26}$ Kwestia systemowego podziału wiedzy ludzkiej byla w Polsce doby oświecenia często dyskutowana w związku z reformami edukacyjnymi. Przykladowo: ks. Adolf Kamiński w 1774 r. pisał, iż „Można by t $\epsilon$ rzeczy, których się uczymy, dzielić na trzy gatunki, to jest: jedne, w których najwięcej rozum i pojętność waża. i których dochodzimy przez silę duszy poznawająca, takie nazywają się scientiae, jako to teologia, filozofia, geometria, polityka; a drugie znowu, w których najwięcej dokazuje dowcip i imaginacja, te nazwać trzeba by artes, jakie są poezja, muzyka, architektura. Jeżeli jeszcze oprócz talentów umysły potrzebują zręczności, zwać ich można kunsztami, jakie są malarstwo, rysunek, snycerstwo, trzecie zaś, w których sama najwięcej panuje pamięć, te nazywają się po prostu nauki, jako to historia, geografia, krasomówstwo; zaś tych wszystkich nauk używając pomocy, wszystkie je też obejmuje i zwać się może powszechnym umiejętności i nauk zbiorem" (tenże, Edukacja obyuratelska w: Pisma i projekty pedagogiczne doby Komisji Edukacji Narodowej, op. cit., s. 19); Franciszek Bieliński w dziełku Sposób edukacji w XV listach opisany, które do Komisji Edukacji Narodowej od bezimiennego Autora byty przestane R. P. 1775 stwierdza „Cokolwiek jest na świecie, wszystko to podpadając pod zmysły nasze wznieca pojęcie tejże duszy pierwiastkowymi przymioty, pamięcią, rozumem i imaginacją, skąd wypływa trojaki podział wiadomości człowieka, historia, która się do pamięci stosuje, filozofia, którą rodzi rozum, i poetyka $z$ imaginacji utworzona. Pod tym trojakim podziałem wszystkie kunszta i nauki zamykają się" (w: Pisma i projekty'..., s. 84), w przypisie Bieliński powołuje się na d'Alemberta.

${ }^{27}$ H. Kollątaj, O Szkole Glównej Koronnej Akademii Krakowskiej do Prześwietnej Komisji nad Edukacja przelożonej 
Trudno również nie spostrzec pewnych — jak się zdaje, nie całkiem powierzchownych - podobieństw między klasyfikacją z Niektórych wyrazów a często spotykanym w nowszej metodologii i teorii poznania podziałem wiedzy na nauki o naturze i nauki o duchu przyrodoznawstwo i humanistykę.

Zadaniem szkolnictwa wyższego nie jest wyłącznie edukacja, lecz również prowadzenie badań naukowych. Dokonując odkryć i wynalazków, człowiek przejawia swój aktywny, twórczy stosunek do rzeczywistości, nie tylko lepiej poznaje naturę, ale także nabywa — na dobre i na złe - moc kształtowania otaczającego go świata. O sprawach tych kanonik pisze językiem dobitnym i nie pozbawionym elementów wzniosłości. Hasło Nauki rozpoczyna się taką oto konstatacją:

Szkół powinnością jest utrzymywać nauki podając o ni $[\mathrm{ch}]^{28}$ wiadomość albo też wyszukiwać nowych umiejętności i niedoświadczane pokazywać skutki w naturze, gdzie rozum jakby prawdziwy namięstnik Stwórcy, przeinaczając przyrodzenia obrządki, wystawuje nieznajome jestectwa kwoli wygodzie, zdrowiu, potrzebie i częstokroć zbytkowi samemu ${ }^{29}$.

Jezierski zwraca tu uwagę na sprawę, której Komisja Edukacji Narodowej nie poświęcała zbyt wiele baczenia. Co prawda w Ustawach można przeczytać, iż

Komisyja Edukacyi Szkoły Główne w trojakim sposobie chce mieć użytecznymi: w pierwszym uważając je jako towarzystwo ludzi różnymi naukami zaleconych, a czyniących jedno zgromadzenie, z których każdy, oprócz obowiązków do katedry swojej przywiązanych względem dawania lekcyi publicznych, znajdzie w szlachetności swojego serca i gorliwości dla kraju silną pobudkę do rozszerzenia w nim światła i potrzebnych wiadomości, już to przez wydawanie pism w różnych materyjach fizycznych lub moralnych, już to przez odkrywanie prawd użytecznych i wyszukiwanie rozmaitych krajowych produkcyi oraz wydoskonalenie sposobów przydatnego onych użycia ${ }^{30}$,

— były to jednakże tylko slowa, za którymi nie szło ze strony Komisji żadne poważniejsze organizacyjne czy moralne wsparcie. Jednoznaczna opinia Ambroise Joberta — mimo późniejszych prób relatywizacji — pozostaje aktualna:

\footnotetext{
raport od dnia 1 października 1780 do dnia ostatniego miesiąca lipca 1784 roku, w: tenże, Raporty o wizycie i reformie Akademii Krakowskiej, opr. M. Chamcówna, Wrocław 1967, s. 193. Odpowiedni punkt ustaw brzmi: „Podlug podziałı nauk na fizyczne i moralne dwa będą collegia; do pierwszego należeć będą nauki teologiczne, prawne, historyi, krytyki, literatury i tym podobne, do drugiego nauki matematyczne, fizyczne, historyi naturalnej, medycyny i tym podobne" - Ustawy Komisji Edukacji Narodowej (r. 1783), w: Komisja Edukagi Narodowej. (Pisma Komisji i o Komisji). Wybór źródel, opr. S. Tync, Wroclaw 1954, s. 589-590.

${ }_{28} \mathrm{~W}$ pierwodruku jest „niej”.

${ }_{29}$ F. S. Jezierski, Niektóre wyrazy..., s. 139.

${ }^{30}$ Ustawy Komisji Edukacji Narodowej, op. cit., s. 581.
} 
Zadne wielkie dzieło literackie ani glośne odkrycie naukowe — pisze francuski historyk - nie wsławiło szkół głównych. Komisja Edukacyjna nawet tego od nich nie wymagała. Prymas Poniatowski nie pozwolił Jaśkiewiczowi na ponowienie doświadczeń aerostatycznych, zniechęcił Szkołę Główną Koronną do podjęcia korespondencji z paryską Akademią Nauk, której nawiązanie proponował Cousin. Ogłoszone po polsku dzieło Śniadeckiego Rachunku algebraicznego teoria przystosowana do linii krzynych znalazło tak niewielu czytelników, że mlody profesor zrezygnował $z$ prac badawczych na rzecz nauczania i prac organizacyjnych $^{31}$.

W haśle Edukacyja kanonik, podobnie jak w oracji lubelskiej, sugestywnymi słowy wyraża myśl, iż sprawa tak istotna jak wychowanie młodzieży musi być pod dozorem administracji państwowej. Jak to często miewał w zwyczaju, myśl tę wyraża w postaci aforystycznego porównania:

Edukacyja, choćby najlepsza, nie może mieć powagi, tylko od władzy krajowej; tak złoto i srebro, kruszcze szacowne, przecież nie mogą mieć beśpiecznej wartości na zapłatę rzeczy, tylko pod stemplem krajowym ${ }^{32}$.

Przy porównaniu ze sobą mowy przed Trybunalem Koronnym i rzeczonego hasła, oprócz wielu calkiem zrozumiałych różnic zachodzących pomiędzy dwoma tekstami tego samego autora, traktującymi co prawda o podobnej tematyce, ale pisanymi w różnym czasie i z różnym przeznaczeniem, można napotkać jedną, która budzi zastanowienie.

Otwarciem oracji lubelskiej jest paradoksalna wypowiedź, iż w dziejach ludzkości wszystkie kraje były ojczyznami ojców, a nie dzieci. Rozpatrywane hasło kończy się podobną wydawałoby się na pierwszy rzut oka - sentencją. Sentencja ta jest poprzedzona króciutkim wywodem o niemożliwości ułożenia dobrego systemu edukacji przez społeczeństwo ogarnięte demoralizacją:

...jeżeli naród który na świecie wyzuty z cnoty, z sprawiedliwości, z rozsądnego sposobu myślenia, zanurzony w występkach i nawet dający im poklask i przebaczenie ohydne; możeż ułożyć naród taki prawidła edukacyi? ${ }^{33}$

Zdanie kończące Edukacyję brzmi

Naród, który nie jest porządną ojczyzną dla ojców, tym trudniej, aby miał być porządną ojczyzną dla dzieci ${ }^{34}$.

Myśl nieuczesana, a nawet niepokorna, zamienia się w myśl przyzwoicie wygładzoną.

\footnotetext{
${ }^{31}$ A. Jobert, Komisja Edıkacji Narodowej w Polsce (1773-1794). Jej dzieło wychowania obyvatelskiego, th. M. Chamcówna, Wrocław 1979, s. 117.

${ }^{32}$ F. S. Jezierski, Niektóre wyrazy..., s. 35.

${ }^{33}$ Ibidem, s. 36.

${ }^{3+}$ Loc. cit.
} 


\section{Lustracja stanu reformy edukacyjnej}

Od początku roku szkolnego 1784/1785 funkcję rektora wydziału małopolskiego sprawuje ks. Wincenty Treffler ${ }^{35}$. Franciszek Salezy Jezierski opuścił Lublin i przeniósł się do Krakowa - miał nadzieję na objęcie katedry uniwersyteckiej. Nadzieja ta okazała się plon$\mathrm{na}^{36}$. Szkola Glówna na posiedzeniu 12 marca 1785 roku wybiera Jezierskiego na wizytatora generalnego, Komisja Edukacyjna zatwierdza kandydaturę ${ }^{37}$. Przed samym wyjazdem na wizytację kanonik był rozczarowany i rozgorycznony niespełnieniem się nadziei na profesurę, jego położenie pogarszały jeszcze kłopoty pieniężne.

Nastrój psychiczny byłego rektora małopolskiego oddaje jego list do Kollątaja z 10 kwietnia 1785 roku:

Nie tak z listu JWP Dobrodzieja — żali się Jezierski — (bo ten nie jest dla mnie otwarcie pisany) jak bardziej z listu JWP Mirosławskiego wyrozumiałem moje nieszczęście, któregom się obawiał, to jest, że profesorem nie będę w Akademii. Wiem ja i przeświadczam się, że staranie się JWP Dobrodzieja było takie, jakie czyni honor sercom wspaniałym, gdy sobie założą ukontentowanie w wspomaganiu nędzy, inaczej gdybym myślał we dwójnasób zwiększyłbym moją zgryzotę, ale nie mam na nic składać mojej złej doli, jak tylko na przykrą opatrzność. Osoby mnie przychylne i mające przyjaźn przestrzegały mnie jeszcze w Lublinie i pod Krakowem, nie wierzyłem im zadurzony będąc moją fałszywą nadzieją. Teraz to bardziej trapi mnie żalem, iż pogardziłem radą przyjaciół. Mogła mnie, prawda, czy to Komisyja, czyli Szkoła Główna pozbawić się z Lublina prosto, mniej miałbym szkody przynajmniej. Lecz teraz w Krakowie siedząc na bruku pół roku, gdym długów narobił zjechałem $z$ mojej nadziei i stałem się nieszczęśliwym ${ }^{38}$.

Kołłątaj nie pozostał obojętny na użalania się niedoszłego profesora i - jak można przypuszczać - użył swoich wpływów, aby wydobyć go z trudnego położenia. Niezadługo po nominacji na wizytatora Komisja Edukacyjna powierza dodatkowo Jezierskiemu (na czas

${ }^{35}$ Zob. Protokoty posiedzeń Komisji Edukacji Narodowej 1773-1785, opr. M. Mitera-Dobrowolska, Wroclaw 1973, s. 352.

${ }^{36}$ W protokole posiedzenia KEN z 14 stycznia 1785 roku czytamy: „Komisyja chcąc jeszcze w terániejszym roku szkolnym otworzyć w Szkole Głównej katedrę literatury, dla ćwiczenia kandydatów nieodwłocznie potrzebną, postanowila wezwać do niej zaleconego sobie z obszernej wiadomości i dobrego gustu j. ks. Bogucickiego, dotąd profesora historyi kościelnej; j. ks Salezego Jezierskiego, będącego na urzędzie rektora szkól wydziału małopolskiego, za profesora historyi kościelnej po postąpieniu j. ks. Bogucickiego wyznacza" (tamże, s. 349). Rzecz pozostała w sferze projektów z powodu niezgody Bogucickiego na objęcie katedry literatury. (zob. M. Chamcówna, Uniwersytet Jagielloński $w$ dobie Komisji Edukacji Narodowej. Szkota Gtóvna Koronna w okresie wizyty i rektoratu Hugona Kollqtaja 1777-1786, Wroclaw 1957, s. 229-230).

${ }^{37}$ Zob. H. Pohoska, Wizytatorowie generalni Komisji Edukacji Narodowej. Monografia z dziejów administracji szkolnej Komisji Edukacji Narodovej, Lublin 1957, s. 103-104.

${ }^{38}$ F. S. Jezierski, list do H. Kolłątaja z 10 IV 1785 r., w: Listy z prowincji. Korespondencja wizytatorów generalnych, rektorów i nauczycieli ze Szkołą Gtówną Koronnq, opr. K. Mrozowska, Warszawa 1998, s. 34. 
zagranicznej podróży naukowej bibliotekarza Jacka Przybylskiego) funkcję zastępcy biblio tekarza Szkoły Głównej z pensją czterech tysięcy złotych rocznie ${ }^{39}$. Co chyba mogło pomór Jezierskiemu w rozwiązaniu doraźnych problemów finansowych, jeśli weźmiemy pod uwa gę, iz jego następca na stanowisku rektora wydziału małopolskiego ks. Treffler otrzymywa pobory w wysokości dwu tysięcy dziwięciuset pięćdziesięciu zlotych ${ }^{40}$.

Jezierski wyrusza na wizytację z opóźnieniem spowodowanym niesprzyjającymi warun. kami pogodowymi ${ }^{41}$. Wyjeżdża uświadomiony o celach swej inspekcji nie tylko oficjaln instrukcją przyjętą na obradach Szkoły Glównej 3 kwietnia, lecz ponadto i listem od Kollątaja wzywającym do starannej kontroli odwiedzanych szkól. Pisał rektor Akademii Krakowskiej

Przesławszy na ręce JPana sekretarza [J. Śniadeckiego - B. T.] potrzebne do wizyty instrukcje (...) uznałem jeszcze za rzecz do obowiązku mego należąca uczynić do WPana zgłoszenie, którym pragnę go zachęcić do jak najgorliwszego odprawienia funkcji wizytatorskiej, ażeby tak gorliwym Komisji zamiarom dogadzając zjednać mu mogłą powszechną szkoły wdzięczność i względy najwyższej nad edukacją zwierzchności ${ }^{42}$.

Szczególnie mocno zaznacza Kołłątaj nieodzowność przeglądu kompetencji osób kierujących poszczególnymi zgromadzeniami szkolnymi. Sugeruje, by wizytator nie wahał si przed stanowczymi decyzjami personalnymi.

Wizytator, chcący dogodzić życzeniom Komisji powinien się najprzód zastanowić nad zdolnością i charakterem przełożonych każdego zgromadzenia, od tego albowiem wszystko zależy. Póki nie będziemy mieli przełożonych oświeconych, zdolnych do rządzenia, łagodnych, sprawiedliwych, kochających swe powołanie i przekonanych o dobroci Ustaw Komisji, póty cała nasza budowa na nic się nie przyda. Dlaczego ${ }^{43}$, w ciągu niniejszej wizyty, zechcesz WPan dać

\footnotetext{
${ }^{39}$ W Protokotach Komisji Edukajii Narodowej pod datą 31 maja 1785 roku znajduje się następujące postanowienie: „Komisyja do zastąpienia urzędu bibliotekarza przy Szkole Glównej Koronnej w czasie trzechletnim oddalenia się na wojaż JP Przybylskiego wyznacza J. ks. Jezierskiego, kanonika kaliskiego, wizytatora generalnego szkół narodowych, w czasie wolnym od wizy mieszkać mającego przy Szkole Glównej, z obowiązkiem znajdowania się na obradach onejze cum voto decisivo, któremu $z$ tego powodu i pensyja bibliotekarza po złp. 4000 rocznie w przeciągu trzech lat służyć będzie, zaczynając a 1 Octobris roku teraźniejszego (...)": (Protokoly..., op. cit., s. 432). Jednakże w wydatkach na rok akademicki 1785/1786 i 1786/1787 przewidzianc dla Jezierskiego wyplatę roczną w wysokości 2000 zl (zob. Protokoty posiedzeń Komisji Edukacji Narodowej 1786/1794, opr. T. Mizia, Wrocław 1969, s. 8, 31, 73).

to Zob. ibidem, s. 352.

+1 "Lubo już by dziś trzeba być w drodze według rozporządzeń Komisyi dla wizytatorów, jednakże ja jeszcze $z$ Krakowa piszę i jeszcze nie wyjadę z niego, aż chyba na końcu teraźniejszego miesiąca. Nie ja jestem przyczyną, tylko natura, mamy tak wielkie śniegi, iz ludzie o kilka mil ruszyć się nie mogą" (list do H. Kołłątaja z 10 IV 1785 r., op. cit., s. 34).

t2 List H. Kołlątaja do F. S. Jezierskiego, po 20 marca 1785, w: Instrukcje dla wizytatorów generalnych szkót Komisji Edukacji Narodowej 1774-1794, opr. K. Bartnicka, I. Szybiak, Wrocław 1976, s.67.

${ }^{43}$ Tu rzecz jasna w znaczeniu: „połączenie przyimka dla z dopełniaczem lp zaimka co, równoważne z wyrażeniem dlatego", w słowniku Doroszewskiego to znaczenie ilustrowane jest cytatem z Listóv Anonima Kołłątaja (W. Doroszewski [red.], Stownik języka polskiego, t. 2, Warszawa 1960, s. 136).
} 
najpierwsze oko na przełożonych, jeżeli z ich własnej niezdatności, a tym bardziej z ich oporu nie wyplywa przeszkoda w egzekucji Ustaw. (...) W tym samym czasie gdzie idz[ie o poz]bycie się złych lub nieużytecznych rządców, trzeba oraz myśleć o jak najlepszym wyborze przyszłych ${ }^{44}$.

Były rektor wydziału małopolskiego rzetelnie potraktował swe obowiązki inspekcyjne. Zlustrował więcej szkół, niż zobowiązywała go instrukcja — fakt warty odnotowania, jeśli weźmiemy pod uwagę, iż będący wizytatorem generalnym w tym samym czasie Józef Bogucicki pominąl kilka ze zleconych mu do kontroli placówek ${ }^{45}$. Wizyta na ogół przebiegała spokojnie. Jezierski starał się unikać zadrażnień — przykładem może być poniechanie przeglądu szkół pijarskich w Łomży i Szczucinie. W raporcie z wizyty kanonik wspomina:

Szkoły lomżyńskie i szczucińskie ustąpiłem księdzu prowncyjałowi pijarskiemu, jako wydziałowemu rektorowi, nie chcąc się narazić na przykrość, która by mogła wyniknąć $z$ dwóch wizyt razem; upatrywałem w tym nawet krok wartujący żartu, gdyby albo po mnie ks. Prowincyjał, albo ja po nim w kilka dni wizytę odnawiat ${ }^{46}$.

Wyjątek stanowiła wizytacja szkół podwydziałowych w Łęczycy. Co ciekawe, Szkoła Główna nie zlecała Jezierskiemu kontroli tej placówki ${ }^{47}$. Wszystko zdaje się wskazywać, ze udał się tam z własnej inicjatywy. Osąd, jaki kanonik wystawił szkołom łęczyckim, byl niezwykle surowy. Po pierwsze, wizytator był zdania, iż tamtejsze grono pedagogiczne ma skrajnie niechętny, wręcz pogardliwy stosunek do reform oświatowych wprowadzanych przez KEN. Już samo to nastawienie jest - zdaniem oceniającego - wystarczające, by sformułować wniosek o pełnej nieprzydatności do pracy dydaktycznej.

Profesorowie w tych szkolach mają wielki wstręt do teraźniejszego przepisu nauk; ja jeszcze posądzam ich, że nie mają wyobrażenia na umysłach swoich nowego sposobu uczenia. Mogąż tacy uczyć, którzy nie lubią nauki, którzy nią pogardzają? Dlatego nadglaszając się do sekretarza Szkoły Głównej doniosłem, że trzeba odmienić osoby wszystkie przy szkolach lęczyckich ${ }^{48}$.

" List H. Kolłątaja do F. S. Jezierskiego, po 20 marca 1785, op. cit., s. 68.

${ }^{45}$ Zob. H. Pohoska, op. cit., s. 105-106.

to F. S. Jezierski, Raport wizyty generalnej szkố pińczouskich, kieleckich, radomskich, górskich, warszawskcich akademickich i pijarskich, wegrowskich, drohickich, pultuskich, plockich, lowickich, rawskich, piotrkowskich, tęczyckich, wieluńskich, trzemeszyńskich, poznańskich, wschowskich, rydzyńskich i kaliskich, odprawionej przez ks. ... św. t[eologii] d[oktora], kanonika kolegiaty kaliskiej, dany Szkole Glównej roku 1785, w: Komisyja Edukacyi Narodowej i jej szkoly w Koronie 1773-1794, z. 28: Raporty generalnych wizytatorów z r. 1785, wyd. T. Wierzbowski, Warszawa 1914, s. 44-45. H. Pohoska (op. cit., s. 106) uważa, iż dająca się zauważyć u Jezierskiego „Chęć nierozdrażniania pijarów związana była z akcją pijarską, zmierzającą do wyzwolenia szkół tego zakonu spod wizyt generalnych, jaka rozwinęła się w latach następnych”.

${ }^{47}$ Zob. Instrukcje dla wizytatorów generalnych..., s. 63-64.

${ }^{48}$ F. S. Jezierski, Raport wizyty generalnej..., s. 51. 
Po drugie, oprócz prorektora ks. Joachima Więckowskiego i jeszcze jednego z nauczycieli prowadzenie się profesorów łęczyckich jest — raportuje Jezierski - wielce naganne:

Obyczaje nauczycielów łęczyckich podlegają tym wadom: Dopuszczają się pijaństwa, ks. Koniczewskiego widziałem pijanego dwa razy, bawiąc się 4 dni; o inszych zaś miałem powziętą wiadomość od studentów, mieszczan i żydów, że nie tylko upijali się w domu i na mieście, ale nawet i do szkoły przychodzili pijani. (...) profesorowie łęczyccy robią między sobą kłótnie, łają się wyrazami sprośnymi, jeden drugiemu na złość czyni ${ }^{49}$.

Wizytacja łęczycka Jezierskiego i jej pokłosie były przedmiotem mniejszego bądź większego zainteresowania wielu autorów ${ }^{50}$. W wymienionych poniżej w przypisie pracach nie próbuje się poddawać w wątpliwość obiektywności raportu kanonika. Inne stanowisko zajmuje Jan Poplatek. W swej monografii formułuje następującą opinię o Jezierskim jako wizytatorze generalnym:

Poczet wizytatorów zawiera ludzi wykształconych, troskliwych o szkoły, traktujących swój zawód poważnie. (...) Od poprzedników swoich znacząco odbijał kanonik kolegiaty kaliskiej, (...) Franciszek Salezy Jezierski (...). Powołany przez Szkołę Glówną Koronną na wizytatora generalnego, wizytował w r. 1785 szkoły wydziału wielkopolskiego, małopolskiego, mazowieckiego i pijarów. Zaznaczył swój pobyt w szkołach nadto poważnym traktowaniem swego urzędu i sprawy, pochopnością do uogólniania i przesady, złośliwością w wyrażanych uwagach i jednostronnym osądzaniem spraw i ludzi często niekonsekwentnym ${ }^{51}$.

Argumentację Poplatka, która prowadzi go do powyżej zacytowanych wniosków, można prześledzić na przykładzie prorektora Więckowskiego. Poplatek, odwołując się do dokumentacji źródłowej, konfrontuje osąd Jezierskiego z werdyktami innych wizytatorów. Przywołuje między innymi raporty Józefa Bogucickiego, Waleriana Bogdanowicza, Franciszka Kolendowicza, Bonifacego Garyckiego:

Bardzo pochlebną opinię zostawil o nim wizytator Bogucicki w lipcu 1784 r. Podniósł on sumienność Więckowskiego w wykonywaniu wszelkich zarzą-

${ }^{49}$ Loc. cit.

${ }^{50}$ Wymieńmy tu przykładowo kilka ważniejszych pozycji: W. Smoleński, Kuźnica Kottqtajouska, s. 281-290; A. Jobert w swej monografii KEN zamieszcza paragraf zatytułowany Sprawa Jezierskiego, zob. Komisja Edukacji Narodowej w Polsce..., s. 177-178; H. Pohoska, Wizytatorowie generalni..., s. 106-109; K. Mrozowska, Walka o nauczycieli świeckich..., s. 168-170; M. Chamcówna, Uniwersytet Jagielloński...., s. 279-280; W. M. Grabski, U źródel twórczości Franciszka Salezego Jezierskiego, „Prace Polonistyczne”, seria XXVII, 1971, s. 209-243; J. Włodarczyk, Problematyka szkót $i$ osiviaty $w$ laudach sejmików lęczyckich, „Zeszyty Naukowe Uniwersytetu Łódzkiego", seria I, 1972, z. 88, s. 145-161.

${ }^{51}$ J. Poplatek, Komisja Edukacji Narodowej. Udzial bytych jezutitów w pracach Komisji Edukacji Narodowej, Kraków 1973, s. 395. 
dzeń Komisji Edukacji Narodowej, jego „stateczną ku dobru powszechnemu gorliwość” (...). Wobec uznania ze strony Bogucickiego niezrozumiałą wprost staje się całkowicie ujemna opinia Jezierskiego z 1785 r. (...). Wśród zarzutów postawionych całemu gronu, jeden dotyczył wyraźnie Więckowskiego. że niechętnie, nawet wręcz wrogo, odnosi się do przepisów Komisji Edukacji Narodowej. Wziął go w obronę w następnym roku wizytator Bogdanowicz, który wprawdzie stwierdził, że rzeczywiście jeden z uczniów (!) uczył się z Alwara, ale nie podtrzymał zarzutów Jezierskiego, o gronie wyraził się dodatnio (chociaż tylko 2 nauczycieli w nim zmieniono), a o prorektorze zanotował same pochwały. Jasny stąd wniosek, że opinia Jezierskiego nie była podyktowana wyłącznie istotnym stanem rzeczy, ale też może innymi względami, bo w przeciwnym razie Kolendowicz, Garycki, Bogucicki, czy wreszcie sam Bogdanowicz, musieliby zauważyć choć ślad tych ciężkich wykroczeń, którymi Jezierski obciążył Więckowskiego i całe grono łęczyckie. 17 marca 1788 r. na posiedzeniu KEN podkreślono wyraźnie, że J. Więckowski należy do nauczycieli najbardziej godnych pochwały i zasługujących na nagrody ${ }^{52}$.

Śmiało można bronić przekonania, iż owe hipotetyczne „inne względy” (o których mówi Poplatek, i które mogły były wpłynąć na tak ujemną ocenę szkół łęczyckich w raporcie Jezierskiego) na pewno nie wynikały z niechęci wizytatora do eks-jezuitów. Na końcu monografii Poplatka zamieszczona jest tabela Opinie wizytatorów generalnych o nauczycielach $i$ kierownikach szkót-bytych jezuitach 1782-1786. Z 14 wydanych przez Jezierskiego ocen eks-jezuitów spoza szkół łęczyckich tylko jedna jest negatywna ${ }^{53}$. W powstałym kilka lat po raporcie Tronie dla próżnej powagi kanonik pisze - przy okazji wzmianki o pierwszym rozbiorze Polski — o „uczonym zakonie” ginącym z powodu „zbytku swego rozumu”:

Wydarzyła jeszcze opatrzność do tego to szczególne przytrafienie, że zakon jeden uczony i bogaty został wyzuty z swej zakonności, wyrokiem najwyższego przełożeństwa w religiji; w jednym czasie dwa wspołeczeństwa ginęły, rzeczpospolita wolnego narodu przez swoje głupstwo i rzeczpospolita tego zakonu przez zbytek swego rozumu. Ogłoszone prawo zniesienia uczonego zakonu tak niegodziwej obradzie krajowej stworzyło wrota kradzieży i łupiestwa. Osoby $z$ senatu i z rycerstwa pozabierały srebra i złota $z$ oftarzy, sprzęty świątnicy obrócone na przepych i oplatę zbytków, inwentarze folwarków, kapitały gotowych i pomieszczonych pieniędzy, dobra w różnej postaci, dochody miawszy wyprowadzone, porozdawane prywatnym. I spełniło się, że to jest znakiem upadającej ojczyzny, kiedy obrzydliwość spustoszenia stanie na miejscu świętym ${ }^{54}$.

52 Ibidem, s. 158.

${ }^{53}$ Zob. ibidem, s. 448-451.

${ }^{54}$ F. S. Jezierski, Tron dla próżnej powagi ..., s. 120-121. 
Istnieją dane źródlowe pozwalające snuć domysły o możliwych powodach łęczyckiej zaciętości Jezierskiego. W swym raporcie wspomina o wcześniejszym, odbytym przy okazji prywatnej podróży spotkaniu z ks. Więckowskim.

Będąc jeszcze rektorem wydziału małopolskiego, jechałem w kompanii Januszewicza, dzisiejszego wiceprofesora prawa w Szkole Głównej, do posesyi mojej w Kaliskiem będącej; przystojność kazała oddać wizytę ks. prorektorowi łęczyckiemu. Cała nasza zabawa na tem zeszła, że ja broniłem rozrządzenia $\mathrm{P}$ [rześwietnej] Komisyi i nowo zaprowadzone nauki, a ks. prorektor łęczycki przeciwko nim następował. Wszakże, że to była rozmowa prywatna, a ks. prorektor nie należał podówczas do mego urzędu, przeto też nie był oskarżony przeze mnie przed zwierzchnością 55 .

Co właściwie wtedy się wydarzyło między księżmi akademikami; jak mocno „następował” ks. prorektor; jak bardzo zdecydowanie „bronił” ks. rektor; czy ktoś poczuł się wówczas wielce urażony? - te i podobne kwestie muszą chyba już na zawsze pozostać w sferze przypuszczeń.

W czasie wizyty Jezierski nie przestawał oddawać się swym zamilowaniom krasomówczym. Jak sam nadmienia:

Ile mi kolwiek przychodziło odwiedzać szkoły, starałem się zastanowić młódź szkolną nad celem, do którego przez edukacyję dążą; to jest: nad tymi obowiązkami, do których się dla ojczyzny przez edukacyję sposobią. (...) ostrzegałem przy tem, że ludzie urodzeni $w$ stanie szlacheckim nie powinni nigdy pogardzać żadną inną klasą obywatelów, a mając zaszczyty z swego własnego urodzenia, obowiązani są tem bardziej starać się o przymioty osobiste, które dopiero potrafią ich uczynić godnymi następcami cnoty swych poprzedników. Wszędzie takowy dyskurs był dobrze przyjęty, prócz województwa łęczyckiego, gdzie powtórzywszy to zdanie, zasłużyłem na niechęć obywatelów $(\ldots)^{56}$.

Czy kanonik swą przemowę do szlachetnej młodzi mianą w Łęczycy nasycił o wiele mocniej piekącą satyrą niż wystąpienia w innych szkołach; czy ostro skrytykowani profesorowie prowadzili przeciw niemu aż tak skuteczną agitację wśród miejscowej szlachty ${ }^{57}$; czy zaszły jeszcze jakieś inne okoliczności?

Znów musimy poprzestać na domysłach. W każdym razie skutek jest znany. Słowa, które wizytator powiedział dzieciom, dały okazję ojcom do podjęcia zdecydowanych kroków.

\footnotetext{
${ }^{55}$ F. S. Jezierski, Raport wizyty generalnej..., s. 51.

${ }^{56}$ Ibidem.

${ }^{57}$ Skonfliktowany z lęczyckim gronem pedagogicznym nauczyciel świecki Teodor Osękowski w liście do Kołłątaja pisal: „(...) doniosłem [Jezierskiemu - B. T.], iż J. ks. ks. eks-jezuici z Łęczycy cale województwo obruszyło [!] na niego za to, iż skasował Alwar, i iż miał mowę, w której — jak ciż sami rozgłaszają — szkalowal ostatnimi słowy cale województwo" (List do Kollątaja z 30 VII 1785, w: Listy z prowincji..., s. 205.
} 
Obywatele zebrani na sejmiku łęczyckim uchwalili dla wysłanników mających wybrać się do Prymasa instrukcję głoszącą, co następuje:

Nie przepomną ciż J. W. Delegowani użalić się imieniem calego województwa naszego przed Jaśnie Oświeconym Księciem Jegomością Prymasem na Imci ks. Jezierskiego, wizytatora generalnego szkół, który po to jedynie zdał się przybył, aby w uszach dzieci naszych zhańbił i znieważył nas wystawiając obelżywie w przemowie swojej do młodzieży mianej rodziców na cel szyderstwa, a satyryczną krytyką swoją dotykając ordery, urzędy, sądowe magistratury i cały stan rycerski. Dopraszać się oraz będą o przyzwoite tegóż Jegomości ks. Jezierskiego ukaranie ${ }^{58}$.

Sprawa nabrała biegu urzędowego. Zaczęły krążyć pisma. Kołłątaj broni Jezierskiego. Nie ukrywa, iż jest osobiście zaangażowany:

Ponieważ J. ks. kanonik Jezierski jest osobą ode mnie rekomendowaną, przeto wszelkie jego postępki, które by albo obrażały obywatelów, albo przynosiły nieukontentowanie J. O. ksciu Imci, albo pomnażały nienawiść ku stanowi akademickiemu, musiały być największym dla mnie zmartwieniem $(. . .)^{59}$.

Rektor Szkoły Głównej Koronnej jako jeden z ważnych argumentów, mających świadczyć o bezpodstawności zarzutów skierowanych przeciwko wizytatorowi, wysuwa niepodobieństwo przypuszczenia, iż mógłby on wystąpić w roli złośliwego satyryka:

...bo żeby tak mówić, jak jest w punktach na ks. Jezierskiego podano, trzeba być wprzód waryjatem albo, na miejscu poważnej funkcyi wizytatora, przyjąć ukryte imię zlośliwego satyryka. Jako zaś tych dwóch rzeczy o J. ksu Jezierskim trzymać nie można, tak łatwo się domyśleć, że tę złośliwą potwarz rzuciła bojaźń profesorów ruszenia się z siedliska zadawnionego nierządu $(\ldots)^{60}$.

Rektor i sekretarz Akademii wysylają na początku października 1785 roku list do księcia prezesa Komisji Edukacyjnej Michała Poniatowskiego z prośbą o decyzję w sprawie niefortunnego wizytatora:

...rozważając zarzuty przeciwko Jks. Jezierskiemu, tak mocno ciążące na sercach wszystkich, przecztawszy w liście, 19 [Septem]bris ze Skierniewic do W. Rektora pisanym, że JOWKs-ca Mść ząadasz szczególnie wytłómaczenia się na piśmie od Jks. Jezierskiego, postanowiła Szkola Gl[ówna] natychmiast $z$ posiedzenia swego upraszać z najpowinniejszym uszanowaniem, abyś ją

\footnotetext{
${ }^{58}$ Teki Pawińskiego, nr 13: Akta sejmikowe województwa łęczyckiego IV 1733--1792, k. 715-716, rps Biblioteki PAN w Krakowie 8330.

${ }^{59}$ H. Kołłątaj, list do S. Holowczyca z 17 IX 1785, op. cit., s. 335.

${ }^{60}$ Ibidem, s. 336.
} 
JOWKs-ca Mść Dobr. uwadomić raczył, czyli odpowiedź, na usprawiedliwienie się od Jks. Jezierskiego podana, zaspokaja zupełnie tak JOWKs-cą Mść, jak godne województwa łęczyckiego obywatelstwo, czyli też Szkoła Gł[ówna] ma przystąpić do dalszego $z$ Jks. Jezierskim czynienia? ${ }^{61}$

Prymas zakomumikował w liście z 19 listopada, iż zechciał zamknąć sprawę. Polecił, by kanonik złożył obowiązki wizytatora i swą działalność oświatową ograniczył do pełnienia obowiązków bibliotekarza w Akademii Krakowskiej ${ }^{62}$.

Po śmierci kanonika Kołłątaj, powracając pamięcią do wydarzeń sprzed kilku lat, takimi oto słowy opisuje rozstanie się Jezierskiego z pracami pedagogicznymi:

Zwierzchność edukacyjna ulegająca życzeniom obywatelskim (które choć nie zawsze są sprawiedliwe i pożyteczne, meneżowane jednak bywają) wstrzymałą dalsze prace wizytatora. Zaczym, doznawszy niesprawiedliwości zgromadzenia, którego użytecznym dla narodu mógł byl być członkiem, sprzykrzył sobie obowiązki takowe, w których prawda uprzedzeniu ulegać musiała, a zostawszy koadiutorem kanonii krakowskiej oddalił się od obowiązków stanu nauczycielskiego $^{63}$.

\section{Satyra jako metoda edukacji?}

Nie należy wszakże zapominać, iż do dyspozycji zainteresowanych jest jeszcze jeden bez wątpienia godny specjalnej uwagi - komentarz do wizyty łęczyckiej. Komentarz pióra samego Jezierskiego.

Jarosza Kutasińskiego herbu Dęboróg, szlachcica tukowskiego, uwagi nad stanem nieszlacheckim $w$ Polszcze $e^{64}$ to pismo okolicznościowe ${ }^{65}$. Jego powstanie związane jest $\mathrm{z}$ ważnym epizodem z dziejów Sejmu Czteroletniego, z memoriałem miast i utarczkami publicystycznymi, jakie wokół postulatów mieszczan były toczone. Jarosz Kutasiński, narrator pierwszoosobowy, to szarak wywodzący się z zaścianka nieopodal Łukowa. Pomysł, na którym oparta jest konstrukcja dziełka, daje kanonikowi doskonałą sposobność zwalczania orężem śmiechu i satyry antymieszczańskich uprzedzeń w mentalności szlachty. Nie tylko niedorzeczne, ale i nieprzeparcie komiczne są przesycone megalomanią wyobrażenia siedzącego na zagonie i ledwo wiążącego koniec $z$ końcem szlachetki o jego przyrodzonej przewadze nad każdym łykiem — niech to będzie nawet bankier, kupiec albo wlaściciel kamienicy.

${ }^{61}$ H. Kollątaj, J. Śniadecki, list do Michała Poniatowskiego z 9 X 1785, w: Korespondencja Jana Śniadeckiego. Listy $z$ Krakowa, opr. L. Kamykowski, Kraków 1932, s. 443-444.

${ }^{62}$ Zob. ibidem, s. 444.

${ }^{63}$ H. Kołlątaj, Przedmowa, w: F. S. Jezierski, Niektóre wyrazy..., s. XIII.

ot Wyd. Warszawa 1790.

${ }^{65}$ Por. E. Rabowicz, Okolicznościowa literatura polityczna, w: Stownik literatury polskiego ośiviecenia, red. T. Kostkiewiczowa, Wrocław 1994, s. 349. 
Rozpatrywany utwór, niezależnie od uwikłań w bieżącą politykę, jest bez wątpienia wartościowym, wielowymiarowym dziełem literackim. Narrator w opowiastce Jezierskiego nie jest drewnianym, pozbawionym indywidualnych rysów produktem retoryki publicystycznej. Jego uwagi i wynurzenia są nasycone subiektywizmem, osobistymi obserwacjami pełnymi obrazowych szczegółów obyczajowych (choćby naszkicowanych tylko za pomocą kilku słów) z życia codziennego - wlasnego i otaczających go ludzi: rodziny, kolegów szkolnych, podróżnych spotkanych na gościńcu... Stąd chyba bierze się możliwość różnych - wcale nie sprzecznych ze sobą - interpretacji owej niewielkiej objętościowo książeczki. Przykładowo: Włodzimierz Bolecki w komentarzu krytycznym do Diogenesa $w$ kontuszu Wacława Berenta pisze:

Tematem Jarosza Kutasińskiego... są zatem przesądy, mity i uprzedzenia jako formy myślenia warstw czy klas społecznych. Jest to jakby literacko przedstawiona problematyka socjologii wiedzy ${ }^{66}$.

Zaniedbajmy tu polityczną, socjologiczną i jeszcze inne możliwe interpretacje Jarosza, zogniskujmy uwagę na odczytaniu tego utworu jako opowieści edukacyjnej ${ }^{67}$. Nasz bohater poczuł się zagubiony wśród mnogości przeciwnych opinii, sądów i mniemań o sprawie miejskiej.

Wśód takich rozważeń mnogości, gdy jedni piszą za miastami, żądającymi stanu w Rzeczypospolitej, drudzy przeciw miastom, inni zaś twierdzą, że wszyscy blądzą, zastanowiłem się uwagą, na którą by stronę przystać z sposobem mojego myślenia ${ }^{68}$.

Szczęśliwie napotkał na swej drodze czlowieka, który udzielił mu krótkiej instrukcji na temat metody poznawanie prawdy. Jak się zdaje, ów „człowiek osobliwy” udzielił Jaroszowi całkiem niezłych, choć nieco ogólnikowych porad.

Potrzeba, mówił on, przystępować do poznawania prawdy pracowicie, ale nie skwapliwie, należy ją obejrzyć z daleka, obejść wokoło, przypatrzyć się ze wszystkich stron, wstąpić na sam jej wierzch i zstąpić zgłębiając się aż do gruntu jej zasad 69 .

${ }^{66}$ Zob. W. Berent, Opowieści biograficzne, opr. W. Bolecki, Kraków 1991, s. 465.

${ }^{67} \mathrm{~W}$ określeniu tym nawiązuję do terminologii zaproponowanej przez Z. Sinko: „Powieść edukacyjna przedstawia bohatera-szlachcica, który uczestniczy w szeregu wydarzeń i sytuacji, będących dlań kolejnymi etapami zdobywania życiowej edukacji i ksztaltowania pogladów na społeczno-kulturalne i obyczajowe sprawy wspótczesnego mu świata" (eadem, Pouvieš́, w: Stownik literatury polskiego osiviecenia, s. 457). W przypadku Jarosza Kutasińskiego nie może być oczywiście mowy o powieści, dlatego używam określenia „opowieść”.

${ }^{68}$ F. S. Jezierski, Jarosza Kuttasińskiego herbu Dęboróg, szlachica hukowskiego, uwagi nad stanem nieszlacheckim w Polszcze, Warszawa 1790, s. 9.

${ }^{69}$ Ibidem, s. 10. 
Kutasiński postanawia przeanalizować koleje swego losu, aby dojść do własnego stanowi ska w kwestii miejskiej, i co za tym idzie, by uświadomić sobie swe własne miejsce w refor mującym się spoleczeństwie:

...obrałem sobie przejść myślą przez całe życie moje, przypominając sobie, $\mathrm{w}$ jakim położeniu miałem zdanie względem stanu miejskiego w sposobie mego myślenia. Sposób taki wyszukiwania prawdy musi pomieścić krótko zebraną historyją życia mojego, ile do tego zamiaru wyciąga potrzeba, ponieważ życie każdego czlowieka jest siedliskiem prawdy albo nieprawdy ${ }^{70}$.

Pod koniec tychże metodologicznych rozważań Jezierski wkłada w usta pierwszoosobo. wego narratora swej powiastki ważne stwierdzenie:

Rodziemy się na to, abyśmy myślili, jak kiedy sądziemy o rzeczach i dlaczego w czasie odmieniamy nasze przeszle rozumienie o nich ${ }^{71}$.

W przytoczonym zdaniu zawarta jest myśl o możliwości przekształcenia nawet głębokc uwewnętrznionej postawy społecznej, wyzbycia się anachronicznych przesądów stanowych przyswojenia bardziej oświeconych wyobrażeń obywatelskich i państwowych.

Kiedy wspólnie z Jaroszem Kutasińskim przyglądamy się jego życiu, widzimy, iż w młodości dwie osoby wywarły nań szczególnie duży wplyw. Pierwszą z nich był ojciec karmiący go legendami herbowymi i genealogicznymi, drugą nauczyciel w szkole, nie ukrywający swej słabości do celnej satyry społecznej. Jarosz na całe życia zapamiętał, jak to pewnego razu w porze śniadania

...pan Władysław Kutasiński, ojciec mój, który chodzil do szkół aż po retorykę, począł opowiadać historyją herbowną i początki zaszczytów familii Kutasińskich $^{72}$.

Syn z dumą chłonął opowieści ojca:

Osobliwszy początek herbu był zaszczytem urodzenia mego, tak jak mitologija grecka w genealogiji bogów bajecznych: Minerwa się poczęła z mózgu Jowisza, Wenera z morskiej piany, a dom Kutasińskich z dębu i rogów jelenich. Dziękowałem Opatrzności przeznaczenia, że nie idę od Chama, tak jak chłopy, i że nie jestem wzgardzony jak lyczaki mieszczanie, ale ze jesetm prawdziwej krwi szlacheckiej karmazyn ${ }^{73}$.

\footnotetext{
${ }^{70}$ Loc. cit.

${ }^{71}$ Ibidem, s. 10-11. W pierwodruku zdanie to wyróżnione jest kursywą.

72 Ibidem, s. 17-18.

${ }^{73}$ Ibidem, s. 19.
} 
Co prawda obraz ten nie był wcale w rzeczywistości tak piękny jak w bajce herbowej. Jarosz nieraz mógł zaobserwować, jak jego ojciec boryka się z niedostatkiem.

...mój ojciec, będąc człowiekiem z urodzenia, z przypadku i z opiniji szlachcicem, z majątku rolnikiem, z niedostatku młynarzem, szewcem, krawcem, bednarzem itd., z potrzeby zaś był chłopem, robiąc wicesgerenszczyznę, która była na kształt pańszczyzny, a ile polował na wilki dla sędziego zabawy, wyręczał powinność ogara $(. . .)^{74}$.

Cóż za budujący widok: pater familias w roli psa myśliwskiego!

Ziarno zwątpienia w wyznawany zespół wartości, stereotypów i legend kastowych zostaje zasianie w szkole. Wysłany na naukę do Eukowa Jarosz spotyka profesora, który karmi jego umysł heretyckimi, głoszonymi z satyrycznym zacięciem prawdami:

Ten prosty człowiek, który najpierwszy sposób wynalazł solenia śledzi, choć był wzgardzony ze swego sposobu życia przez rozumienie przesądu, przecież on się stał dobrodziejem narodu, sprowadził milijony zarobku swemu krajowi i więcej dokazał, jak wszystkie urojonej zacności zaszczyty ${ }^{75}$;

...ani Homer, ani Wirgilijusz nie pisze w swoich wierszach, kto pierwszy wynalazł sposób pieczenia chleba, gotowania mięsa, (...) tylko natomiast piszą o Achillesie, Ulissesie $\mathrm{i}$ innych mordercach rodzaju ludzkiego, jakoby była większa zasługa wojować, przenosząc panowanie narodu od narodu, niż uczynić wynalazek $(\ldots)^{76}$;

...mieszczanin wymurowawszy dom na 100 lokciach gruntu, a wyniósłwszy do góry na 40 łokci, ma z niego dochody większe, jak wieś odległa od miasta, a mająca tyle ziemi, ile ma całe miasto $(\ldots)^{77}$.

Z owymi profesorskimi naukami, które zapoczątkowały ferment w głowie Kutasińskiego, związane jest jedno jedyne ${ }^{78}$ napomknięcie odnoszące się do wypadków z życia samego Jezierskiego. Satyryczna tyrada oświeconego pedagoga, z której pochodzą powyższe wyimki, opatrzona jest następującym przypisem:

Jeden akademik wizytujący szkoły, gdy w podobnym sposobie myślenia o szlachcie mówił do młodzieży szkolnej w jednej prowincyi, takie to zrobiło oburzenie serc najpierwszych obywateli, iż przeciw niemu podano oskarżenie

$7+$ Ibidem, s. 15.

75 Ibidem, s. 23-24.

76 Ibidem, s. 25.

77 Ibidem, s. 27.

78 "Jeśli są jakieś momenty autobiograficzne w Jarosza Kutasińskiego... uwvagach..., to chyba tylko passus o nauczycielu” (J. Michalski, [rec.] Franciszek Salezy Jezierski, „Wybór pism”. Opracowat Z. Skwarczyński, PIW, 1952, „Przegląd Historyczny”, t. 44, 1953, s. 628). 
do przełożeństwa nauk krajowych, od którego zostal ukarany złożeniem $z$ urzędu i pozbawieniem stanu akademickiego, w którym kilka lat pracowat ${ }^{79}$.

Nie trzeba zbyt dużej wyobraźni historycznej i socjologicznej by pojąć, iż takie satyrycznı ekskursy mogły nieźle irytować tradycjonalistów. Ale czyż to zirytowanie nie było świadectwem skuteczności edukacyjnej satyry?

Ciekawa i nie pozbawiona satyrycznej werwy — jak świadczy załączony poniżej rozdzia z Rzepichy - jest przeprowadzona przez Jezierskiego krytyka edukacji dworskiej.

${ }^{79}$ F. S. Jezierski, Jarosza Kutasiniskiego... uwagi..., s. 24, przyp. autora. 


\section{Franciszek Salezy Jezierski}

\section{Życie domowe Piasta podczas panowania i rozmowa jego w Gnieźnie z żoną o wychowaniu młodzieży z okazyi syna swego Semowita}

\section{Opracował Bronisław Treger}

$\mathrm{U}$ dzielanie się rządowi powszechnemu w kraju zostawiało część czasu Piastowi około zabaw jego osobistych jako człowiekowi. Dla ludzi pracujących siłami umysłu tak jest potrzebna zabawa, jak dla każdego człowieka spoczynek i posiłek. Lecz zażywać tego podług umiarkowania jest dziełem cnoty i roztropności. Dozór domowego zarządzenia był mu częścią zabawy; przyuczony całe życie do pomiarkowania i do znajomości, jak wiele czego powinno wystarczać, miał upodobanie przezierać wydatki i dochody, jakby ruch opatrzności biorący obrót wielkiemi kołami teraźniejszej jego fortuny. Wychowanie roślin, pielęgnowanych dowcipniejszą sztuką wynalazku ludzkiego w ogrodach, zastanawiało zmysły i serce tego pana, cieszył się, że człowiek, namiestnik Stwórcy nad widomym światem, umie rozumu zażyć na zjednanie pożytku z darów jego. Myślistwa i łowy zwierza były częścią zabawy; jest wyrządzeniem rozrywki umysłowi wypleniać bestyje szkodliwe z ziemi, które natura zostawiła na przeszkodę mieszkańcom ${ }^{1}$. Widoki igrzyska w owych wiekach nie były w inszym sposobie, jak bieganie jeźdzców na koniach, i sztuki zapaśnicze; to pokazywało razem pręd-

\footnotetext{
' Gdy jednowładztwo panuiących monarchów po narodach Europy nie znało granic prawa, zrobili oni sobie wynalazek rozrywki z okrutnego myślistwa, kędy folgując zwierzom uciskano ludzi. Nie godzi się zabić nikomu np.jelenia, albo zająca prócz panującego. Stada więc tych zwięrząt psują zboża, i prócz tego, co ubodzy rolnicy składają podatki na wymysły monarchów; jeszcze dziwactwo ich myślistwa uszczerbek czyni pracy wieśniaków z tego względu [przypis Jezierskiego ozn. „m”].
} 
kość, zwrotność i siłę konia, złączoną z zręcznością człowieka w zażyciu go; sił też wzajem. nych pokazanie w sztuce zapaśniczej bawiło oczy patrzących. Wieku gotyckiego zamiarem było zabawy i widoki zbliżać do waleczności i męstwa, bo naówczas był wiek skłonniejszy dc najazdów wojennych ${ }^{2}$.

Nad wszystkie zaś przymilenia zabaw w stanie książęcym Piasta te byly najprzyjemniejsze, jakie natura wymierzyła dla serca powszechnie wszystkich ludzi, tym była nieustann przychylność z Rzepichą żoną i Semowitem synem. Miłość pierwiastkowa, wzniecając: skłonności serca wzajemnie, nie ma tyle powagi przed sądem prawdy, ile przychylnośc z doświadczenia cnoty i z jej zaufania mieć może między zgodnie zostającemi pod związkiem pożycia. Ten przymiot w swoich uczuciach jest tylko własnością serc cnotliwych, dopók rozpusta nie przeinaczyła go, tak jak monetę w mennicach na fałszywej wartości znaczeniє przemieniło łakomstwo. Zawsze Piastowi w prostym przeświadczeniu jego serca Rzepicha była miłą osobą w młodości, czy w dalszym wieku, w chacie wieśniackiej, lub na zamku książęcym. Jej roztropność, szczerość, wierność, wyciągała od męża uszanowanie, i przez tc obojga serca byly sobie nawzajem otwarte; nie odmieniła się w sposobie myślenia odmiana najwyższego bytu, zamiar jej chęci ten był szczególny być dobrą matką i żoną.

Gdy Piast z żoną, z synem i z calym dworem swoim wyjechał na mieszkanie do Gniezna, cała okolica tego wielkiego miasta uczula przybycie pana. Pierwsze osoby prowincyi obojej płci przybyły oddać z uszanowaniem nawiedziny książęcemu domowi. Na te wszystkie okazalej wielkości przysmaki, za jakiemi zwykła się uganiać miłość wlasna, obojętną zostawała Rzepicha, ani młodym kobietom zazdroszcząc wdzięków, ani nad rówienniczki wynosząc się dostojeństwem; lubo zbyt często nieszczęśliwe doświadczenie znać daje, że piękna płeć tak na wielkim świecie podlega odmianom, jak kolor wysokiej farby prędko na wilgotnym powietrzu płowieje, przechodząc żądaniem z jednego na drugie dziwactwa. Jak wiele stolice państw poprzemieniały osób tej płci w postępkach, z wyzuciem spokojności mężów, a z czasem $z$ wyzuciem ich majątku, i nawet $z$ ogołoceniem się z dobrej sławy!

Księżna Rzepicha w tak nagłym wyniesieniu do najwyższej dostojności według przystojności używała wszystkiego, jedynym zamiarem serca mając męża i syna. Semowit, w pierwiastkowym dzieciństwa wieku będąc dla rodziców zabawą i pociechą, w dalszych latach przez wychowanie miał się stać zakładem nadziei domu panującego i całego narodu. Nigdy troskliwość rodziców nie może sprawiedliwiej zastępować serca, jak w wychowaniu i ćwiczeniu potomstwa. Między powabami wielkości, której każdy lubi sobie obiecywać nadzieję, jest też i ta, gdy z dobrego potomstwa czeka się wsparcia honorem calego imienia. Lecz jak we wszystkich przedsięwzięciach omija skutek nadzieję, tak też i w tym, bo albo natura umknie zdatności, albo nauki stosowane będą nie do potrzeb rozsądku, i nie do pojmowania rzetelnej prawdy.

\footnotetext{
2 Teraz zaś wszystko osłodzone w oświeconym wieku: miasto gonitw rycerskich i zapasów, teatra widoków, pomieściły w poezyi i muzyce namiętności serc ludzkich najłagodniejsze dla obyczajów skromności, tej to cnoty, która powinna być zawsze przyjaciółką wstydu [przypis Jezierskiego ozn. „n”].
} 
Właśnie Rzepicha, stojąc razu jednego z swym mężem przed wielkim przysionkiem zamku gnieźnieńskiego, patrzyła na Semowita bawiącego się z wesołością dziecinnego wieku, i rzekła:

- Nie tylko wychowanie tego dziecięcia należy do naszego serca, ale nawet do uszczęśliwienia calej słowiańskiej ziemi.

Odpowiedział Piast:

- Nie trzeba w tym zakładać przesadnej pieczołowitości; bogowie opatrzni założyli w naturze ludzkiej, co jest użytkiem dla zamiaru człowieka, każdy powinien być cnotliwy, i każdy powinien być znajomcą prawdy, rozsądek idąc prostą drogą, dojdzie cnoty, obaczy przeszkody przeciwne jej w skażytelności żądań nieporządnych. Wychowany młodzieniec jeżeli od dzieciństwa nauką i przykładem ugruntuje sposób myślenia porządny, będzie się zawsze wola jego obracać za prawdą, a prawda pokaże mu świattem swoim powinność czlowieka, dopelnienie zaś powinności zrobi go szczęśliwym i cnotliwym. Bo jeżeli by tych prawideł nie było w naturze ludzkiej, za cóż by się sumienie ${ }^{3}$ upominało za przestępstwa swojemi wyrzutami, albo za co by miała być ta niesłuszność w opatrzności, żeby człowieka stwarzając w stanie prostego wychowania, w ubogim domie, miała się od niego upominać cnoty i prawdy, kiedy ta zawisłaby tylko od wytwornych sposobów ćwiczenia młodzieży pańskiej? Musi być owszem wychowanie ludzi co do ich obyczajów poczciwych powszechne, na jednostajnych prawdach praw natury zasadzone, a podług tego pozyskanego w dzieciństwie światła dopiero sposobić się można nauką do wykonania potrzeb w obowiązkach stanu, w jakim się znajdować będzie na całe życie.

Ja wszakże, wiadomo bogom i ludziom, że byłem synem prostego rzemieślnika, ty byłaś córką wieśniacką; powszechne wychowanie obojga nas pod przykładem cnoty i pod jej ustawicznym widokiem w sprawowaniu się tych, z któremiśmy żyli, zjednało nam na dalsze życie, żeśmy w sprawiedliwości utrzymywali potrzeby naszego domu, ażeśmy do tego przystąpili przeznaczenia, że nas wybrano do najwyższego przełożeństwa nad całą ziemią słowiańską, i jeżeli łaskawi bogowie będą się opiekiwać nami, wystarczy nam w samym naturalnym rozsądku, jako w powszechnym źrzódle ich daru, oświecenia, jak sobie będziem postępować rządnie i słusznie. Te wszystkie przewrotne niesprawiedliwości, te dowcipne kłamstwa i wyspoczenia ${ }^{4}$ prawdy, są owocem, że pierwiastki w wychowaniu nie obracały rozumu do poznawania rzetelnej prawdy, i że serce zaraz się skłaniało za swemi pożądliwościami. Takie wychowanie obróciło rozum na usługę przewrotności, a przewrotność na dogadzanie niesłusznych zamysłów ${ }^{5}$, i to wyrabia, że w społeczeństwach wiele widzieć można osób uczonych i rozumnych, ale mało poczciwych; i lubo cnota jest tak pięknym przymiotem natury, że każdy choć kłamliwie lubi się nazywać poczciwym, już jednak w źle wybudowanym sposobie myślenia nie ostoi się cnota w sercu pod złym przykładem wychowanego dziecięcia.

\footnotetext{
${ }^{3}$ W wyd. drugim, s. 241, mamy „sumnienie”.

+ U Lindego czytamy: „wyszpacać, wyspaczać, szpetnie wykrzywić, wykrzywiając oszpecić, wyszpecić” (S. B. Linde, Stownik jezzyka polskiego, t. 6, cz. 1, Lwów 1860, s. 624). W wyd. drugim, s. 242, jest „wyboczenia”. ${ }^{5}$ W wyd. drugim, s. 242 - „niesłusznym zamysłom”.
} 
W domach w[ielmożnych $]^{6}$ imion (które będąc przybytkiem cnoty przodków, są częstokroć mieszkaniem osobistych niecnot) gdy rodzice sprawowaniem swoim różne tworz: między ludźmi rozumienia o sobie, gdy potomstwo ich nie widzi, tylko bogactwa i kłamstwa gdy w poranku życia unoszą się za zmysłami w rozkoszach, podchlebstwie i zbytkach, tan ani rozum obrócony na stronę prawdy, ani serce nie nakłonione do cnoty. Cóż więc z tego: Oto wyrastają panięta, rodzice zakładają brzemię umiejętności na ich rozum, przyjmuja nauczycielów, i ci ozdabiają wiadomościami i językami pamięć; będą więc z nich nierozsądn mędrce, rozpustni mężowie, nierządni gospodarze. Tacyż to ojcowie dzieci, jakiemi byli sam w wychowaniu swoim, ladaco obywatele, najczęściej marnotrawcy majątku, i słowem ludzie u których przewodzące namiętności zawsze przewyższać będą w sercu prawdę. Społeczeństwo nazywa ich godnemi ludzmi, oni sami nazywają się poczciwemi, prawda zaś twierdz i sumienie ${ }^{7}$ własne (jeżeli go tylko słuchają), że to są mędrcy upstrzeni umiejętnością, że tc są następcy wielkich przez cnotę i zasługi domów, do której oni teraz nic a nic nie należą prócż wspólnego imienia.

Dlatego, moja Rzepicho, naszemu Semowitowi dawajmy wzór do cnoty, aby w nie zabierał przykład, i żeby tak był poczciwy $z$ naszego sprawowania się, jak jest czlowiekiem: $z$ naszej krwi. Im wyżej fortuna wynosi swoim obrotem kolebkę dziecięcia, tym go bardziej przybliża do przeszkód słuszności i cnoty, i łatwiej się pod uciskiem nędzy opierać występkom, jak nie upadać pod zbyt szczęśliwym powodzeniem. Semowit syn nasz, będąc następca tronu, co do swoich okazalych powinności w dalszym życiu powinien mieć przysposobione wychowanie, wcześnie na tę stronę obrócone poznawanie prawdy i pełnienie cnoty. Bo prawda i cnota jest zamiarem wychowania dziecięcia, czyli się to rodzi do pluga lub do berła. Lecz zażycie prawdy i cnoty wymierzyla opatrzność odmianą tylu rozróżnionych stanów: Semowit nasz syn, ile przyszły książę, mający być głową ziemi słowiańskiej, powinien stosować rozum do poznawania obowiązków swojego dostojeństwa, to jest: on powinien być rządnym gospodarzem i swojego książęcego domu, i swojego państwa. W narodzie rolniczym, gdzie korzyści bogactwa zasadzone są na samych potrzebach istotnie należących do życia, łatwiej dobrym rządem pomiarkować można wydatki $z$ dochodami, jak w narodzie kupieckim albo rzemieślniczym.

Semowit powinien być przezornym sędzią swojego ludu, bo on ma mieć najwyższą władzę, i do niego uciśniony wyciagać będzie rękę; a jeżeli zwykło się serce wzruszać politowaniem, aby bliźniemu pomóc w potrzebie, jakże dopiero najwyższy przełożony ludu nie powinien się poczuwać do szacunku sprawiedliwości? Tu wszystkich sił roztropności potrzeba, w rozeznawaniu i sporów prawnych i osób wyznaczonych do namiestniczych sądów; zgoła Semowit mając być książęciem, powinien być powierzonego ludu obrońcą, zasłaniając od napaści ojczyznę swoję; w tym razie należy mu mieć męstwo i dzielność w zażyciu sil

${ }^{6} \mathrm{~W}$ tekście skrót „W. W.”.

7 W wyd. drugim, s. 244 - ,sumnienie”. 
wlasnych i sił własnego ludu, nie powinna go unosić chęć fałszywej chwały okrutnych zwycięzców, zakładających wielkość w rozlaniu krwi ludzkiej. Nie powinien być skwapliwym na walkę, ale powinien być ostrożnym i przezornym w obronie swoich poddanych. Te powinności wyciągnione rozumem z prawdy, jeżeli ozdobi przymiotami, i cnotą nasz Semowit, my z czasem spokojnie wstąpiemy do grobu, pójdziemy w łono wieczności, zostawiwszy cnotę w krwi następców dla dobra ludzkości.

\section{Notka edytorska}

Przedrukowany tekst to XIX rozdział Rzepich $y$ Franciszka Salezego Jezierskiego. Podstawą niniejszej edycji było pierwsze wydanie: Rzepicha, matka królów, żona Piasta, między narodami sarmackimi stowiańskiego monarchy tej częśi ziemi, która się nazyua Polska, Warszawa 1790, s. 324-341. W przypisach uwzględniono ciekawsze odmianki tekstu z pośmiertnego wydania drugiego: Warszawa 1794, s. 234-246.

Pisownia i interpunkcja zostały zmodernizowane, tak by nie naruszyć żadnych ważnych własności osiemnastowiecznej wymowy, fleksji i składni. Niniejsza publikacja zalicza się, ogólnie rzecz biorąc, do rodzaju określonego w Zasadach wydawania tekstów staropolskich jako typ $\mathrm{B}^{8}$. Oprócz prawidel transkrypcji zalecanych w Zasadach... uwzględniono dodatkowe reguły zaproponowane przez Janusza Maciejewskiego ${ }^{9}$.

${ }^{8}$ Zob. M. R. Mayenowa [red.], Zasady wydawania tekstów staropolskich. Projekt, Wrocław 1953.

${ }^{9}$ Zob. J. Maciejewski, Zasady edycji okolicznościowej literatury politycznej XVIII wieku, „Napis”, seria III, 1997, s. 185-192. 